\title{
Nurses' knowledge and Attitudes toward Elderly Patient's Rights and Code of Ethics at Assiut University Hospital
}

\author{
Asmaa B Hassan, Safaa A Kotb, Asmaa Gh Mohammed. \\ Nursing Specialist at Technical Nursing Institute, Assiut University \\ Assistant Professor of Community Health Nursing, Faculty of Nursing, Assiut University.
}

\begin{abstract}
Background: Values are essential in order to maintain the Elderly Patients' Rights. Aim of the study: to assess knowledge and attitudes of nurses regarding elderly patients' Bill of Rights and Code of Ethics at Assiut University Hospital. Subject and methods: 400 nurses participate and descriptive cross-sectional study design was used.. Total coverage technique was used. Data collection started from 1 July - 31 December 2013. Tools: an interviewing questionnaire used for data collection, it contained three parts: assess personal data, assess nurses' knowledge toward code of ethics; and elderly patients' rights, assess nursing attitudes toward code of ethics and elderly patients' rights. Results: $33.8 \%$ of the studied nurses had experience in nursing work 5-10 years. The studied nurses had satisfactory knowledge toward code of ethics and elderly patients' rights', (65\% and59.2\%) respectively. Regarding to gender factor; females represent significant high score of knowledge toward code of ethics than males.Conclusion: It was concluded that education level and gender can affect the knowledge level of the nurses. Recommendations: involving the professional values and elderly patients' rights in nursing educational curriculum, and implement an educational program for updating nurses' knowledge .
\end{abstract}

Key wards: Elderly, Patients' Rights, Code Of Ethics, Nurses, Knowledge, \& Attitudes.

\section{Introduction}

The composition of the world population has changed dramatically in recent decades. Between 1950 and 2010 life expectancy worldwide rose from 46 to 68 years, and it is projected to increase to 81 by the end of the century. For the first time in human history, in 2050, there will be more persons over 60 than children in the world (World Population Prospects, 2011).

Health of individuals, of communities, of environments (interior and exterior), and the world is the first priority of nurses. Nurses are key in mobilizing new approaches in health education and healthcare delivery in all areas of nursing ( Karph, et al, 2010).

These factors often contribute to ethical dilemmas for nurses. To work through ethical dilemmas, nurses need to have knowledge of and assimilate nursing professional values that nurses use to develop solutions. The professional values of nursing assist the nurse in making decisions that are in line with the Code of Ethics for Nurses, the established ethical standard for the nursing profession (Cohen \& Erickson, 2006).

The care of the elderly, frail and sick can be immensely demanding both physically and mentally. For them, ethics is about how they want to be treated and allowed to make their own decisions. For professionals providing eldercare, ethics is about adherence to established canons of ethics promulgated by organizations such as the American Medical Association for physicians, and the American Nurses Association (World Medical Association, 2005).

In respect for the inherent worth, dignity, and human rights of every individual are a fundamental principle that underlies all nursing practice. "Nurses take into account the needs and values of all persons in all professional relationships" With the increasing numbers of acute and chronic health conditions experienced by elders, nurses are in key positions to provide disease prevention and health promotion, and to promote positive aging (American Nurses Association, 2012).

Study Rational

The estimated proportion of the population of elderly people (older than 65 years) in Egyptian society is about 4.4\% at the beginning of 2013 (Central Agency for Public Mobilization and Statistics, Egypt, 2012).

Despite the growing numbers of older people, especially in Egypt, their situation was unfortunate, their rights and their needs were ignored, and came at a late stage of the interests of the state, and there was no real awareness of the individuals that take care of the elderly (Souad, 2013).

Gerontological nurses encourage and provide the opportunity for older persons to exercise their rights and responsibilities, respect the older person's dignity 
and privacy, and are aware of the factors that contribute to each older person's situation and work with the person to identify what is important to him or her (Gerontological Nurses Association, 2004).

To provide ethical health care, it is important to consider patients' rights as mentioned in different patients' bills of rights or charters published in each country, and code of ethics (Youuf et al., 2009).

\section{Aim of the study}

The study was conducted to

1. Assess nurses' knowledge \& attitude about code of ethics involved in elderly care.

2. Determine nurses' knowledge \& attitude about elderly patient's right

\section{Subject and Methods}

\section{Research design}

The present study is cross-sectional. It was carried out at all inpatient departments in Assiut University Hospital. Assiut University Hospitals was chosen because it is one of the largest educational and therapeutic hospitals in the Arab Republic of Egypt. The sample was calculated by using the following equation: $\frac{z^{2} p \times q}{d^{2}}$

\section{(Lwanga and Lemeshow, 1991)}

Based on prevalence rate of $(50 \%)$ and at a confidence level (95\%) Level of significant is less than (0.05).The total number of sample was (400) nurses in the previous mentioned setting, (184) males, (216) females. The nurses selected by total coverage technique, according to proportional distribution of nurses in Assiut University Hospital.

Tools

Structured interview questionnaire developed by the researcher for data collection based on review of related literature to assess Nurses' knowledge and Attitudes toward Elderly Patient's Rights and Code of Ethics at Assiut University Hospital, it included:

Part I: concerned with personal characteristics of studied sample such as: Nurses' age, sex, educational status, marital status, religion.

Part II: prepared to assess the knowledge of the participants about code of ethics and elderly patient's Bill of rights, this part divided into two subparts: it includes (14) questions that represents the ethical responsibilities of the nurses in each dimension of care those ethical responsibilities subdivided from the Canadian code which based on American Nurses Association code of ethics for nurses. And (8) questions that assumed the main patients' rights at hospital based on Patient's Bill of Rights developed by American Hospital Association (Parvan et al., 2012).

And sub part: was prepared to assess the attitudes of the participants about code of ethics and elderly patient's Bill of rights it include Nursing Professional Values Scale Revised NPVS-R and likert -type scale was developed to assess nurses' attitudes toward patient's Bill of rights. Participants were asked to rate the degree of importance of these items ranging from one equal (not important) to five equal (most important) (Weis and Schank, 2000).

Field Work

An official letter approval obtained from the Dean of the faculty of nursing, Assiut University to the General Manager of Assiut university hospital to conduct the study. The litter included permission to carry out the study and explained the purpose and nature of the study.

Pilot study

Field pre-testing of the questionnaire was carried out on $0.05 \%$ of total sample before its use to test understanding, wording of the questions, and reliability of the instrument. This was done on 20 nurses who were not included in the sample. It also helped us to estimate the time needed to administer and fill out the questionnaire and determine the coding system. Minor wording changes were made to clarify the meaning of certain questions. The internal consistency of the scale in our tool was high; Cronbach's alpha $=0.94$.

\section{Ethical consideration}

The researchers explained the purpose and the nature of the study for each nurse. The nurse had the right to agree or disagree on participation in the study. The nurse was informed that the information obtained was confidential and used only for the purpose of the study.

The researcher started to collect data from first of July 2013, until the end of October 2013. The interview occurred at nurse's room in every department in Assiut University Hospital. Each interview took about (30-40) minutes to fill the questionnaire. Throughout the interview, every answer from the nurses recorded according to designed question in the form, followed by correction and explanation for every wrong answer. Every day from 1 to 4 interviews of forms finished, interviews done at morning, afternoon, or night shift.

\section{Scoring system}

Scoring of the knowledge questions was as follows: a correct answer was given 1 and the incorrect one was given zero. The score of each item summed-up and then converted into percent score (poor $=$ score $<50 \%$, satisfactory $=$ score $50-70 \%$, and good $=$ score $>70$ percentage) (Parvan et al., 2012). 
Regarding the nurses' attitudes Professional Value Scale-Revised the possible scores for each participant ranged from 26 to 130 and Patients' right total scoring for attitude was the possible scores for each participant ranged from 9 to 35(Weis and Schank, 2000)..

Total score was calculated by summing-up and converting into percent score. Nurses' attitude was considered positive if the score was $\geq 60$ percentage and negative attitude if the score was $<60 \%$ (Weis and Schank, 2006).

Statistical design

\section{Results}

Table (1):- Demographic characteristics of the studied nurses at Assiut University Hospital, (n=400).

\begin{tabular}{|c|c|c|}
\hline Variable & No. & $\%$ \\
\hline \multicolumn{3}{|l|}{ Sex } \\
\hline Male & 184 & 46.0 \\
\hline Female & 216 & 54.0 \\
\hline \multicolumn{3}{|l|}{ Age } \\
\hline$<25$ years & 115 & 28.8 \\
\hline $25-$ & 108 & 27.0 \\
\hline $30-$ & 102 & 25.5 \\
\hline$\geq 35$ years & 75 & 18.8 \\
\hline Mean \pm SD (Range) & \multicolumn{2}{|l|}{$28.95 \pm 6.34(19-53)$} \\
\hline \multicolumn{3}{|l|}{ Residence } \\
\hline Rural & 199 & 49.8 \\
\hline Urban & 201 & 50.2 \\
\hline \multicolumn{3}{|l|}{ Religion } \\
\hline Moslem & 315 & 78.8 \\
\hline Christian & 85 & 21.2 \\
\hline \multicolumn{3}{|l|}{ Qualification } \\
\hline Nursing Diploma & 234 & 58.5 \\
\hline Nursing Technical Institute & 115 & 28.8 \\
\hline Faculty of Nursing & 51 & 12.8 \\
\hline \multicolumn{3}{|l|}{ Marital status } \\
\hline Single & 150 & 37.5 \\
\hline Married & 215 & 53.8 \\
\hline Divorced & 24 & 6.0 \\
\hline Widow & 11 & 2.8 \\
\hline \multicolumn{3}{|l|}{ Years of experience } \\
\hline$<5$ years & 89 & 22.2 \\
\hline $5-<10$ years & 135 & 33.8 \\
\hline$\geq 15$ years & 78 & 19.5 \\
\hline
\end{tabular}

The obtained data were reviewed, prepared for computer entry, coded, and analyzed using SPSS version 16. Descriptive statistics (mean, standard deviation, frequency and percentages) were calculated.

Chi square test was used to compare qualitative variables between groups. It was considered significant when P-values were less than 0.05 . Pearson correlation was used to measure correlation between score of knowledge and attitude toward the code and the patient's rights. 
Table (2):- Nurses' knowledge toward definition and elements of code of ethics at main Assiut University Hospital, $(n=400)$.

\begin{tabular}{|l|l|l|}
\hline \multicolumn{1}{|c|}{ Cod of ehics definition } & \multicolumn{1}{c|}{ No. } & \multicolumn{1}{c|}{$\%$} \\
\hline Definition Correct & 12 & 3.0 \\
\hline Incomplete correct & 66 & 16.5 \\
\hline Incorrect & 322 & 80.5 \\
\hline Elements & 12 & 3.0 \\
\hline Correct & 80 & 20.0 \\
\hline Incomplete correct & 308 & 77.0 \\
\hline Incorrect
\end{tabular}

Fig (1) Total score of nurses' knowledge about code of ethics, at main Assiut University Hospital, (n= 400).

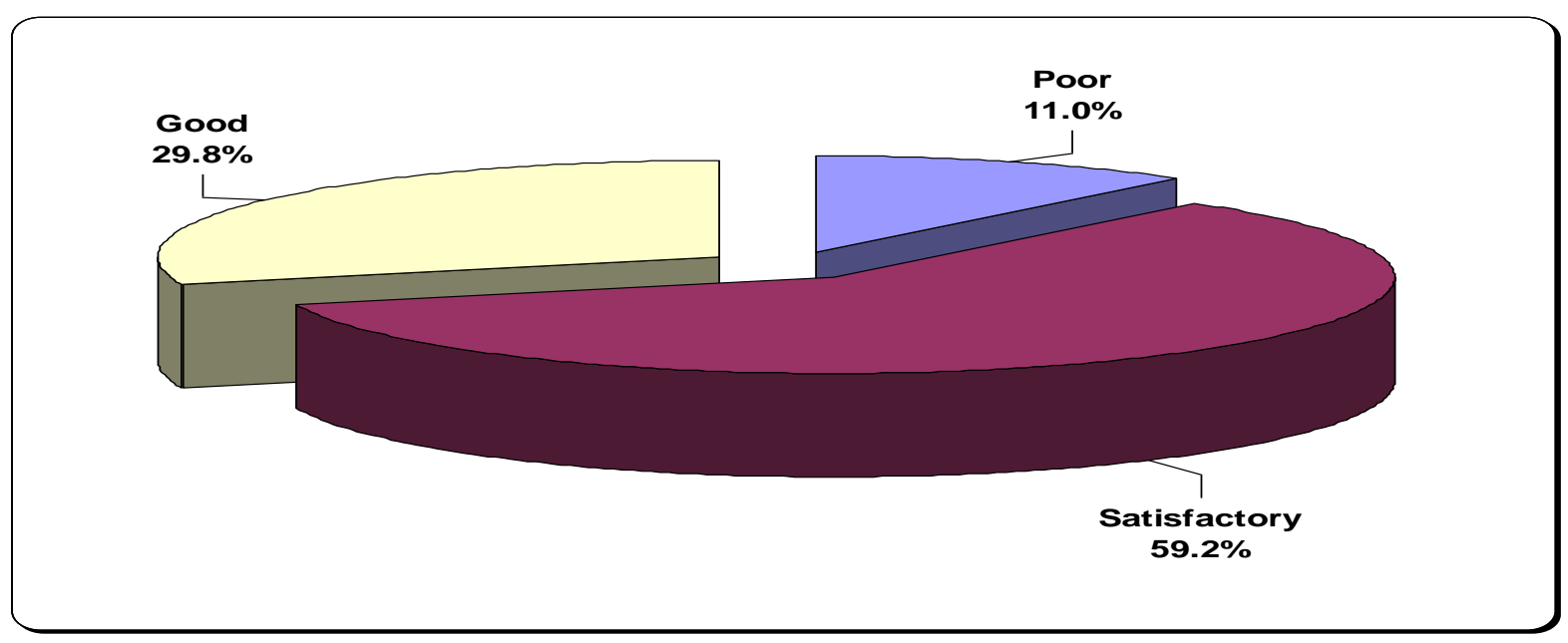

Fig (2): Total score of nurses' knowledge about patient' rights, at main Assiut University Hospital, $(n=400)$.

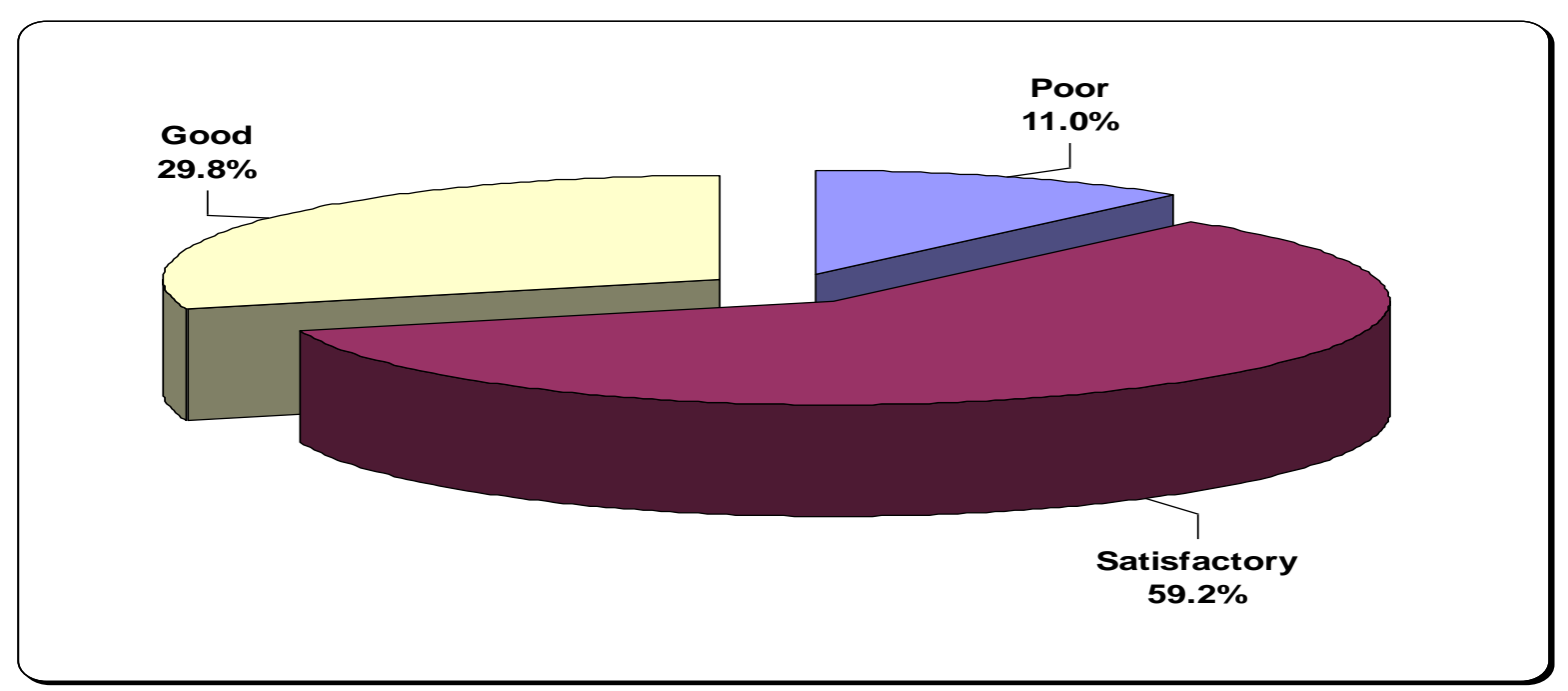


Table (3): Relation between nurses' knowledge about code of ethics and personal characteristics $(n=400)$.

\begin{tabular}{|c|c|c|c|c|c|c|c|}
\hline \multirow{3}{*}{ Variables } & \multicolumn{6}{|c|}{ Knowledge about code of ethics } & \multirow{3}{*}{ P-value } \\
\hline & \multicolumn{2}{|c|}{ Poor $(n=86)$} & \multicolumn{2}{|c|}{ Satisfactory $(n=260)$} & \multicolumn{2}{|c|}{ Good $(n=54)$} & \\
\hline & No. & $\%$ & No. & $\%$ & No. & $\%$ & \\
\hline \multicolumn{7}{|l|}{ Sex } & \multirow{3}{*}{$0.006 *$} \\
\hline Male & 43 & 23.4 & 127 & 69.0 & 14 & 7.6 & \\
\hline Female & 43 & 19.9 & 133 & 61.6 & 40 & 18.5 & \\
\hline \multicolumn{7}{|l|}{ Age } & \multirow{5}{*}{0.728} \\
\hline$<25$ years & 21 & 18.3 & 78 & 67.8 & 16 & 13.9 & \\
\hline $25-$ & 22 & 20.4 & 72 & 66.7 & 14 & 13.0 & \\
\hline $30-$ & 24 & 23.5 & 67 & 65.7 & 11 & 10.8 & \\
\hline$\geq 35$ years & 19 & 25.3 & 43 & 57.3 & 13 & 17.3 & \\
\hline \multicolumn{7}{|l|}{ Residence } & \multirow{3}{*}{0.070} \\
\hline Rural & 44 & 22.1 & 136 & 68.3 & 19 & 9.5 & \\
\hline Urban & 42 & 20.9 & 124 & 61.7 & 35 & 17.4 & \\
\hline \multicolumn{7}{|l|}{ Religion } & \multirow{3}{*}{0.673} \\
\hline Moslem & 65 & 20.6 & 206 & 65.4 & 44 & 14.0 & \\
\hline Christian & 21 & 24.7 & 54 & 63.5 & 10 & 11.8 & \\
\hline \multicolumn{7}{|l|}{ Qualification } & \multirow{4}{*}{$0.000 *$} \\
\hline Nursing Diploma & 58 & 24.8 & 158 & 67.5 & 18 & 7.7 & \\
\hline Nursing Technical Institute & 23 & 20.0 & 80 & 69.6 & 12 & 10.4 & \\
\hline Faculty of Nursing & 5 & 9.8 & 22 & 43.1 & 24 & 47.1 & \\
\hline \multicolumn{7}{|l|}{ Years of experience } & \multirow{5}{*}{0.684} \\
\hline$<5$ years & 17 & 19.1 & 59 & 66.3 & 13 & 14.6 & \\
\hline $5-<10$ years & 24 & 17.8 & 93 & 68.9 & 18 & 13.3 & \\
\hline $10-<15$ years & 25 & 25.5 & 62 & 63.3 & 11 & 11.2 & \\
\hline$\geq 15$ years & 20 & 25.6 & 46 & 59.0 & 12 & 15.4 & \\
\hline
\end{tabular}

Table (4): Nurses' knowledge about Patient Bill of Rights and personal characteristics.

\begin{tabular}{|c|c|c|c|c|c|c|c|}
\hline & \multicolumn{6}{|c|}{ Knowledge about patient rights } & \multirow{3}{*}{ P-value } \\
\hline & \multicolumn{2}{|c|}{ Poor $(n=44)$} & \multicolumn{2}{|c|}{ Satisfactory $(n=237)$} & \multicolumn{2}{|c|}{$\operatorname{Good}(n=119)$} & \\
\hline & No. & $\%$ & No. & $\%$ & No. & $\%$ & \\
\hline \multicolumn{7}{|l|}{ Sex } & \multirow{3}{*}{0.277} \\
\hline Male & 25 & 13.6 & 108 & 58.7 & 51 & 27.7 & \\
\hline Female & 19 & 8.8 & 129 & 59.7 & 68 & 31.5 & \\
\hline \multicolumn{7}{|l|}{ Residence } & \multirow{3}{*}{0.073} \\
\hline Rural & 25 & 12.6 & 125 & 62.8 & 49 & 24.6 & \\
\hline Urban & 19 & 9.5 & 112 & 55.7 & 70 & 34.8 & \\
\hline \multicolumn{7}{|l|}{ Religion } & \multirow{3}{*}{0.477} \\
\hline Moslem & 35 & 11.1 & 182 & 57.8 & 98 & 31.1 & \\
\hline Christian & 9 & 10.6 & 55 & 64.7 & 21 & 24.7 & \\
\hline \multicolumn{7}{|l|}{ Qualification } & \multirow{4}{*}{$0.001 *$} \\
\hline Nursing Diploma & 33 & 14.1 & 141 & 60.3 & 60 & 25.6 & \\
\hline Nursing Technical Institute & 10 & 8.7 & 73 & 63.5 & 32 & 27.8 & \\
\hline Faculty of Nursing & 1 & 2.0 & 23 & 45.1 & 27 & 52.9 & \\
\hline \multicolumn{7}{|l|}{ Years of experience } & \multirow{5}{*}{0.291} \\
\hline$<5$ years & 7 & 7.9 & 62 & 69.7 & 20 & 22.5 & \\
\hline $5-<10$ years & 16 & 11.9 & 80 & 59.3 & 39 & 28.9 & \\
\hline $10-<15$ years & 10 & 10.2 & 56 & 57.1 & 32 & 32.7 & \\
\hline$\geq 15$ years & 11 & 14.1 & 39 & 50.0 & 28 & 35.9 & \\
\hline
\end{tabular}


Table (5): Nurses' attitudes toward patient's rights at main Assiut University Hospital, $(n=400)$.

\begin{tabular}{|l|l|l|l|l|l|l|l|l|l|l|}
\hline \multirow{2}{*}{ Patient's right } & \multicolumn{2}{|c|}{$\begin{array}{c}\text { Not } \\
\text { important }\end{array}$} & \multicolumn{2}{c|}{$\begin{array}{c}\text { When -ever } \\
\text { important }\end{array}$} & \multicolumn{2}{|c|}{ Important } & \multicolumn{2}{c|}{$\begin{array}{c}\text { Very } \\
\text { important }\end{array}$} & \multicolumn{2}{|c|}{$\begin{array}{c}\text { Most } \\
\text { important }\end{array}$} \\
\cline { 2 - 14 } & No. & $\%$ & No. & $\%$ & No. & $\%$ & No. & $\%$ & No. & $\%$ \\
\hline $\begin{array}{l}\text { Treat in a safe, healthy } \\
\text { environment }\end{array}$ & 14 & 3.5 & 52 & 13.0 & 132 & 33.0 & 129 & 32.2 & 73 & 18.2 \\
\hline $\begin{array}{l}\text { Take part in decision } \\
\text { making with regard to his } \\
\text { health }\end{array}$ & 18 & 4.5 & 69 & 17.2 & 147 & 36.8 & 108 & 27.0 & 58 & 14.5 \\
\hline $\begin{array}{l}\text { Take all health services } \\
\text { available. }\end{array}$ & 8 & 2.0 & 66 & 16.5 & 140 & 35.0 & 111 & 27.8 & 75 & 18.8 \\
\hline $\begin{array}{l}\text { Access to information of } \\
\text { hospital. }\end{array}$ & 13 & 3.2 & 80 & 20.0 & 146 & 36.5 & 106 & 26.5 & 55 & 13.8 \\
\hline $\begin{array}{l}\text { Confidentiality and privacy } \\
\text { Approve / refuse to be } \\
\text { included in researches }\end{array}$ & 11 & 2.8 & 76 & 19.0 & 148 & 37.0 & 108 & 27.0 & 57 & 14.2 \\
\hline $\begin{array}{l}\text { Continuity of treatment, } \\
\text { and must be informed of the } \\
\text { option available to others }\end{array}$ & 16 & 4.0 & 70 & 17.5 & 150 & 37.5 & 115 & 28.8 & 49 & 12.2 \\
\hline $\begin{array}{l}\text { Choose health care } \\
\text { providers, place and method } \\
\text { of continuing treatment }\end{array}$ & 25 & 6.2 & 78 & 19.5 & 124 & 31.0 & 113 & 28.2 & 60 & 15.0 \\
\hline $\begin{array}{l}\text { Know / refuse to know any } \\
\text { information about his } \\
\text { health condition \& request } \\
\text { opinion on his condition }\end{array}$ & 17 & 4.2 & 68 & 17.0 & 139 & 34.8 & 99 & 24.8 & 77 & 19.2 \\
\hline
\end{tabular}

Table (6): Relation between nurses' attitudes toward code of ethics and demographic characteristics at main Assiut University Hospital, 2013.

\begin{tabular}{|c|c|c|c|c|c|}
\hline \multirow{3}{*}{ Variable } & \multicolumn{4}{|c|}{ Attitudes toward code of ethics } & \multirow{3}{*}{ P-value } \\
\hline & \multicolumn{2}{|c|}{ Negative $(n=103)$} & \multicolumn{2}{|c|}{ Positive $(n=297)$} & \\
\hline & No. & $\%$ & No. & $\%$ & \\
\hline \multicolumn{5}{|l|}{ Sex } & \multirow{3}{*}{0.289} \\
\hline Male & 52 & 28.3 & 132 & 71.7 & \\
\hline Female & 51 & 23.6 & 165 & 76.4 & \\
\hline \multicolumn{5}{|l|}{ Age } & \multirow{5}{*}{0.690} \\
\hline$<25$ years & 29 & 25.2 & 86 & 74.8 & \\
\hline $25-<30$ years & 24 & 22.2 & 84 & 77.8 & \\
\hline $30-<35$ years & 30 & 29.4 & 72 & 70.6 & \\
\hline$\geq 35$ years & 20 & 26.7 & 55 & 73.3 & \\
\hline \multicolumn{5}{|l|}{ Residence } & \multirow{3}{*}{0.862} \\
\hline Rural & 52 & 26.1 & 147 & 73.9 & \\
\hline Urban & 51 & 25.4 & 150 & 74.6 & \\
\hline \multicolumn{5}{|l|}{ Religion } & \multirow{3}{*}{0.975} \\
\hline Moslem & 81 & 25.7 & 234 & 74.3 & \\
\hline Christian & 22 & 25.9 & 63 & 74.1 & \\
\hline \multicolumn{5}{|l|}{ Qualification } & \multirow{4}{*}{$0.001 *$} \\
\hline Nursing Diploma & 76 & 32.5 & 158 & 67.5 & \\
\hline Nursing Technical Institute & 16 & 13.9 & 99 & 86.1 & \\
\hline Faculty of Nursing & 11 & 21.6 & 40 & 78.4 & \\
\hline
\end{tabular}




\begin{tabular}{|c|c|c|c|c|c|}
\hline \multirow{3}{*}{ Variable } & \multicolumn{4}{|c|}{ Attitudes toward code of ethics } & \multirow{3}{*}{ P-value } \\
\hline & \multicolumn{2}{|c|}{ Negative $(n=103)$} & \multicolumn{2}{|c|}{ Positive $(n=297)$} & \\
\hline & No. & $\%$ & No. & $\%$ & \\
\hline \multicolumn{5}{|l|}{ Years of experience } & \multirow{5}{*}{0.741} \\
\hline$<5$ years & 22 & 24.7 & 67 & 75.3 & \\
\hline $5-<10$ years & 31 & 23.0 & 104 & 77.0 & \\
\hline $10-<15$ years & 28 & 28.6 & 70 & 71.4 & \\
\hline$\geq 15$ years & 22 & 28.2 & 56 & 71.8 & \\
\hline
\end{tabular}

Fig (3) Total nurses' attitudes toward Code of ethics at main Assiut University Hospital, $(n=400)$.

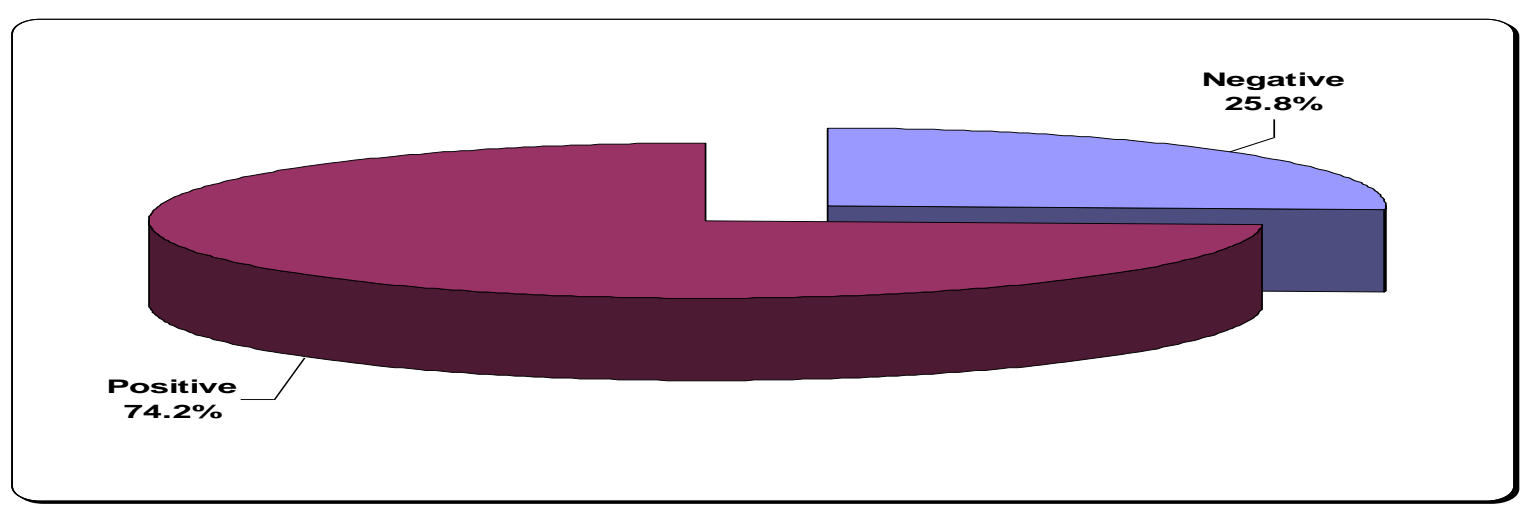

Fig (4) Total nurses' attitudes toward patient's rights and at main Assiut University Hospital, $(n=400)$.

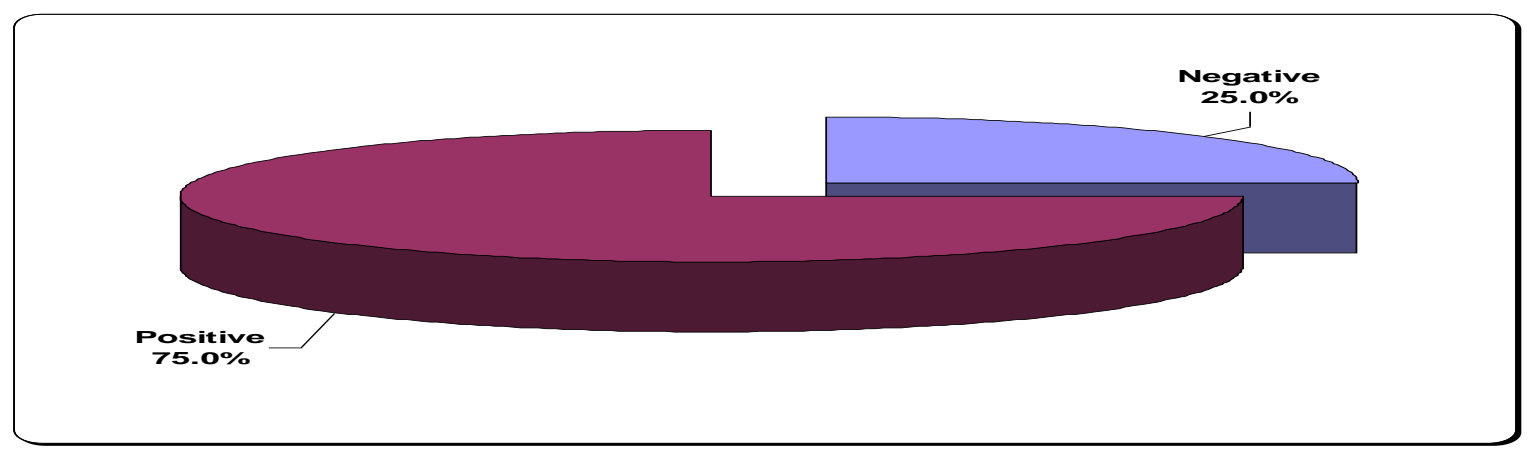

Table (1) : The present study included 400 nurses who included in this study. It was noticed that more than half (54\%) were females, more than half $(53.8 \%)$ were graduated in Technical Nursing School and $(53.8 \%)$ of them were married concerning. The study findings revealed that about one third $(33.8 \%)$ of the studied nurses had a five to ten years of experience, and (19.5\%) had 15 years and more of experience

Table (2) : reveals that the majority of the studied nurses $(80.5 \%)$ couldn't define the code of ethics correctly and (77.0\%) didn't know the elements of the code of ethics, on the other hand (3\%) only knew the correct answer.

Figure (1) : showed that about $13.5 \%$ of the studied nurses had good knowledge in which $65 \%$ of them had satisfactory knowledge toward code of ethics. In which Figure (2) : showed that more than half $(59.2 \%)$ of studied nurses' had satisfactory knowledge about patient' rights, in which $(11 \%)$ of them had poor knowledge about patient' rights.

There is statistical significance difference between the studied nurses and their sex in which females' nurses showed better knowledge than males, and baccalaureate nurses had better knowledge about code of ethics more than other nurses' categories as illustrated at Table (3) : also there are showed that the studied nurses revealed significant differences in their knowledge toward elderly patient's rights, as baclurreate nurses have better knowledge than other nurses' catigories and least percentage of poor 
knowledge than other nurses' catigories that involved in the study as showed at Table (4).

The studied nurses in responding to professional value asked to determine the importance of each statement from (not important $=1$ to most important=5), their choices ranging between important to very important in 24 value statement, except statement number 1,15 that ranging from whenever $=2$ important to important $=3$, as Table (5) shows.

Table (6) : reveals the studied nurses' attitudes towards elderly patients' rights. It indicates that majority of the studied nurses believe that (The patient has the rights be treated in a safe, healthy environment, and The patient has the right to up to all health services available such as: emergency treatment and rehabilitation services to special needs, treat fatal diseases (AIDS), and counseling) are the least important elderly patients' rights, respectively $(3.49 \pm 1.04, .45 \pm 1.04)$.Also they show that(Patient has the right to choose health care providers to him, place and method of continuing treatment, and The patient has the right to expect the continuity of treatment at the hospital, and must be informed of the options available to others) consider the most important elderly patients' rights, respectively (3.49 \pm 1.04 , and $3.28 \pm 1.02)$.

As Table (7) : shows that there is significant difference, as the studied nurses with associated degree (Technical Institute) illustrated positive attitude toward code of ethics more than the other nurses' categories in the study.

Figures (3) : show about three quarters $(74.2 \%)$ of the studied nurses had positive attitudes toward the code of ethics. In which Figures (4) show that three quarters $(75 \%)$ of the studied nurses had positive attitudes toward patient's rights.

\section{Discussion}

American Nurses' Association, 2001, reported that Caring for patients in a professional manner is a main focus of the Code of Ethics for Nurses. Nurses are expected to care for patients with a respectful, competent, and non-judgmental manner. Components of professionalism include respect, confidentiality, and patient advocacy (Blais et al., 2006).

This result showed that more than half $(54 \%)$ of participants were females, the same of (Fagan, 2006) conducted the study in California (USA) state University about Ethical changes in the nursing students, found that the majority of participants Caucasian/white and female, (Martin et al., 2003) conducted the study in Texas about Measured professional values of graduating associate degree and baccalaureate degree nursing students, who found that the sample included $87 \%$ female and $13 \%$ males.

There was a significant difference between sex of the studied nurses and knowledge in the professional value questionnaire, in which females' nurses show better knowledge than males.

These results may be indicated because around half of the studied nurses $(47.1 \%)$ who illustrated good knowledge were baccalaureate nurses, who graduated of Faculty of nursing, Assiut University, that exclusive on females.

Professional values are standards for action and provide a framework for evaluating behavior. In all nurses groups in the present study, the majority of the studied nurses $(87.0 \%)$ described nursing professional values most often in behaviors or terms related to the Patient Care theme, (Building a confidence relationship with the patient) was the common response most often used by the studied nurses in the theme of providing ethical care to the patients.

This findings agreed with that reported by (Debra et al., 2009) that conducted a study in Griffith University about A study of education and experience in nursing students and nurses, who found that participants' description of nursing professional values was in term related to patients' care, however, (respect) was the common response most often used in the theme of Patient Care.

In the present study there were significant association between the educational level and knowledge toward professional values, almost the studied nurses that had good knowledge were baccalaureate nurses.

Unlike the results of (Debra et al., 2009), the baccalaureate degree students had a lower percentage in all three themes from first level to last level of education, unlike the associate degree student response that represent better knowledge.

In the present study, there was a statistically significant relation between educational level and knowledge toward patients' rights, in which around half $(52.9 \%)$ of the baccalureate studied nurses showed good knowledge, whenover about quarter onlyof the associated, and diploma nurses, showed good knowledge, respectively, $(27.8 \%$, and $25.6 \%)$. It may related to the advancement of the curriculum in the university level education, that introduce ethics as a main part in the curriculum in Nursing Faculty, Assiut University.

The results of the present study were showed that the knowledge of the studied nurses (1.5\%) were extremely low to definition of patient's rights, about quarter $(26.0 \%)$ had incomplete correct answer, and more than three quarter (72.5\%) incorrect answer.

The findings are consistent with (Saad, 2011), conducted a study in Central Saudi Arabia, about 
Assessing knowledge of the patient bill of rights in central Saudi Arabia: a survey of primary health care providers. The study showed that about half $(48.8 \%)$ of PHC staff had "little or very little" knowledge about the patient's bill of right contents.

In the present study nurses characteristics were statistically significantly related to their knowledge, with qualification, in which around half of baccalaureate nurses $(52.9 \%)$ had good knowledge about patient's rights more other studied nurses' catigories. These results were in agreement with (Jezewski et al., 2006).

Interestingly, the study found that $(11 \%)$ of the studied nurses were not aware of the inception of the Patient's Bill of rights and less than third of them $(29.8 \%)$ who were aware, knew about its contents as well, and more than half $(59.2 \%)$ of them had only satisfactory knowledge.

This results contracted with (Nyrhinen, 2009) study, about, Are patient rights to information and selfdetermination in diagnostic genetic testing upheld? A comparison of patients' and providers' perceptions, there were a general notion that health care providers possess higher levels of awareness about patient rights and other ethical health issues. However, the results of this study imply that more efforts are needed to promote the knowledge of health care providers about the bill and its contents.

The present study indicated that the studied nurses consider the value "Maintain competency in area of practice." Trust factor as the lowest mean scores of the studied nurses.

While (Clark, 2009; Lin et al., 2010; Schank \& Weis, 2000) studies indicated that the activism factor mentioned previously obtained the lowest mean scores of the nursing students or nurses.

The present study's results showed that two top caring factor statements rated by the participants were "Maintain confidentiality of patient 3.32 \pm 1.08 " and "Protect moral and legal rights of patients 3.37 $\pm 0.96 "$.

This results are agreed with (Parvan et al., 2012), study showed that the two top caring factor statements rated by the participants were "Maintain confidentiality of patient" and "Protect moral and legal rights of patients" in the caring factor statements.

\section{Conclusion and Recommendations}

It was concluded that more than half of the studied nurses have satisfactory knowledge toward elderly patient's rights and code of ethics, however their knowledge considered better at elderly patient's rights than code of ethics. The results revealed significance difference between male and female in their knowledge toward code of ethics, as femal showed better knowledge than male. Also there was a significant differences in the studied nurses' knowledge toward elderly patient's rights, as baclurreate nurses have better knowledge than other nurses' catigories and least percentage of poor knowledge than other nurses' catigories that involved in the study. Generalization of Egyptian Code of Ethics for Nursing Profession to all governmental and private hospital at Egypt, availability of Egyptian Code of Ethics for Nursing Profession to all interested people at online, and raising the nurses' awareness about code of ethics and elderly patients' rights through curriculum during educational process can be done to elevate the nurses' level toward knowledge and attitudes about the code of ethics and patient's rights.

\section{References}

1. American Nursing Association (2012): Complete Code of Ethics for Nurses with Interpretive Statements.

2. Blais, K., Hayes, J., Kozier, B., \& Erb, G., (2006): Professional nursing practice: Concepts and perspectives, 5th Ed, PP 31-35, New Jersey: Pearson Prentice Hall.

3. Central Agency for Public Mobilization and Statistics, Egypt, (2012).

4. Clark D., (2009): Professional values: a study of education and experience in nursing students and nurses. Public Health Nursing, Vol 21(2), pp 191-198. PhD Dissertation, Capella University.

5. Cohen, J., \& Erickson, J., (2006): Ethical dilemmas and moral distress in oncology nursing practice. Clinical Journal of Oncology Nursing, Vol 10(6), pp 775-782.

6. Debra K., Professional values (2009): A study of education and experience in nursing students and nurses, Journal of nursing, Vol., 3(6), pp 1183-1191.

7. Fagan, J., (2006): Ethical changes in the nursing student. College of Health anf Human Services California State University, Journal of Health management, vol 1, pp 1-7; 2006.

8. Gerontological Nurses Association, (2004).

9. Jezewski, M., Meeker, M., \& Robillard, I., (2006): What is needed to assist patients with advance directives from the perspective of emergency nurses? Journal of Emergency Nursing, vol 31(20), pp 150-155.

10. Karph, J., Ferguson, and R., Swift, "Light Still Shines in the Darkness: Decent Care for All," Journal of Holistic Nursing 28, no 4 (2010): 266-274. 
11. Lin Y., Liching Sung W., Yarbrough S., Alfred D., Martin P., (2010): Changes in Taiwanese nursing student values during the educational experience, Journal of Nursing Ethics, vol 17: pp 646-654.

12. Martin, P., Yarbrough, S., \& Alfred, D., (2003). Professional values held by baccalaureate and associate degree nursing students. Journal of Nursing Scholarship, 35(3), 291-296.

13. Nyrhinen T., Hietala M., Puukka P., LeinoKilpi H., (2009): Are patient rights to information and self-determination in diagnostic genetic testing upheld? A comparison of patients' and providers' perceptions, Pub Med 2009; vol 18: pp 72-81.

14. Parvan Kobra, Zamanzadeh Vahid and Hosseini Fahimeh Alsadat, (2012): Nursing students' perspectives on professional values in the universities of medical sciences in Iran, International Research Journal of Applied and Basic Sciences. Vol., 3 (6), 1183-1191, 2012 Journal for Nurses in Staff Development. 15(5) pp 185-192.

15. Saad A., Alghanim (2011): Saudi Arabia Assessing knowledge of the patient bill of rights in central Saudi Arabia: a survey of primary health care providers, Annals of Saudi Medicine, vol 32, issue 2, pp 151-155.

16. Schank M., Weis D., (2000): An instrument to measure professional nursing values. Journal of Nursing Scholarship, vol 32(2): pp 201-204.

17. Souad Abdel Rahim, (2013): a sociology professor at the National Center for Criminal and Social Research, Journal of Al-Ahram Al Arabi, vol 46128, pp 3-4.

18. Weis D., Schank M., (2000): An instrument to measure professional nursing values. Journal of Nursing Scholarship, vol 32(2): pp 201-204.

19. Weis D., Schank M., (2006): Development and Psychometric Evaluation of the Nurses Professional Values Scale-Revised, Journal of Nursing Measurement, Volume 17, Number 3.

20. World Medical Association (2005): Declaration of Helsinki , Ethical Principles for Medical Research Involving Human Subjects . vol (2005).Helsinnki; Finland :(1964). Www. patientsrightscoalition. org/PatientResources.aspx www.patienttalk.info/AHAPatient_Bill_of_Rights.htm on November 30, 2011.

21. World Population Prospects (2011): The (2010) Revision, available from http://esa.un.org/unpd/wpp/unpp/panel_indicator s.htm. 